healthcare workers in the United Kingdom are associated with work overseas in areas of high prevalence of HIV. The low rate of completion of the recommended course of post-exposure prophylaxis indicates the importance of regular support during the four weeks of the course.

In March 2000 a six month follow up form was introduced that asks retrospectively for evidence of the healthcare worker's post-exposure infection status. Although transmissions of HIV among healthcare workers after recorded exposures are unlikely to go unrecognised, assessing transmission rates of hepatitis $\mathrm{C}$ virus requires routine testing. No seroconversions have occurred among the 142 healthcare workers for whom post-exposure testing for hepatitis $\mathrm{C}$ virus has been formally reported $(95 \%$ confidence interval $0 \%$ to $3.35 \%)$, indicating a lower risk of transmission of this virus than has been reported elsewhere. ${ }^{45}$ However, only 102 exposures were due to percutaneous needlestick injury, and only 65 of these were from a hollow bore needle. Such exposures probably do carry a considerable risk of transmission of hepatitis $\mathrm{C}$ virus. One report of such a transmission was received, but the exposure occurred in 1996, before the enhanced surveillance period.

Although exposures to hepatitis B virus among vaccinated individuals may not be well reported, the 151 occupational exposures recorded here indicate the continuing importance of maintaining rigorous programmes of vaccination of healthcare workers.
The Occupational Exposure Surveillance Advisory Group, which gave helpful comments, comprised: Mark Bale and David Mullooly (Health and Safety Executive); Janet Carruthers, Paul Grime, and Lynne Risi (occupational health department, King's College Hospital); Eric Monteiro (genitourinary medicine clinic, Leeds General Infirmary); Susan Turnbull (Department of Health); Sian Williams (occupational health department, Royal Free Hospital); David Goldberg and Fiona Raeside (Scottish Centre for Infection and Environmental Health); Howard Vaile, Caroline Ireland, and Stella Sawyer (occupational health department, Chelsea and Westminster Hospital); Carole Fry (Department of Health); and Jane Watts (occupational health department, Charing Cross Hospital). We thank Janet Mortimer of the Communicable Disease Surveillance Centre for providing constructive comments on drafting, and Pauline Rogers for statistical advice

Funding: JB and then WD were supported by a grant from the Health and Safety Executive.

Competing interests: None declared.

1 UK Health Departments. Hepatitis B infected health care workers: guidance on implementation of Health Service Circular 2000/020. London: Department of Health, 2000.

2 UK Health Departments. Guidance for clinical health care workers: protection against infection with bloodborne viruses. London: Department of Health, 1998.

3 Needlestick transmission of HTLV-III from a patient infected in Africa [editorial]. Lancet 1984;ii:1376-7.

4 Cardo DM, Bell DM. Bloodborne pathogen transmission in health care workers: risks and prevention strategies. Infect Dis Clin North Am 1997;11:331-46.

5 Dore GJ, Kaldor JM, McCaughan GW. Systematic review of role of polymerase chain reaction in defining infectiousness among people infected with hepatitis C virus. BMJ 1997;315:333-7.

(Accepted 20 October 2000)

\title{
Issues in the management of prisoners infected with HIV-1: the King's College Hospital HIV prison service retrospective cohort study
}

\author{
Simon Edwards, Melinda Tenant-Flowers, Joseph Buggy, Peter Horne, Nick Hulme, \\ Philippa Easterbrook, Chris Taylor
}

Correspondence to: Simon Edwards SEdwards@cichs-tr. nthames.nhs.uk

continued over

BMJ 2001;322:398-9

\section{bmj.com}

This article is part of the BMJ's randomised controlled trial of open peer review. Documentation relating to the editorial decision making process is available on the BMJ's website
Concern has been raised about the quality of health care provided to prisoners in England and Wales. ${ }^{12}$ The management of prisoners infected with HIV-1 is challenging: a high proportion are injecting drug users, there are issues regarding confidentiality, and administering complex antiretroviral regimens may be difficult in prison. We reviewed our experience of providing specialist HIV care to prisoners between October 1994 and July 1999.

\section{Participants, methods, and results}

In October 1994, King's College Hospital was contracted to provide care to male prisoners with HIV-1 and sexually transmitted diseases at Wandsworth and Brixton prisons in south London. Prisoners access the service through self referral or referral by wing officers and prison healthcare workers.

Between October 1994 and July 1999 six prisoners were newly diagnosed as positive for antibodies to HIV-1 and 121 said that they had previously tested positive for antibodies to HIV-1. Of those 121, 75 were confirmed as positive for antibodies to HIV-1 and 25 tested negative for antibodies to HIV-1. Fourteen of the remaining 21 who declined to be tested gave information to support their claim, including their HIV treatment centre. In all cases this information proved to be false. Documented reasons for this subterfuge included the desire for a letter pleading mitigating circumstances in court or a request for food supplements, sedatives, or opioids.

Of 81 patients confirmed as positive for antibodies to HIV-1, $77 \%(62 / 81)$ were white and $16 \%(13 / 81)$ were black-African. The median age at first assessment in prison was 33 (range 23-65) years and the main HIV risk factor recorded was injecting drug use (59\%; 48/81). The median CD4 count was $210 \times 10^{6} / 1$ (range $\left.4-740 \times 10^{6} / 1\right)$ and a fifth were severely immunosuppressed $\left(\mathrm{CD} 4<50 \times 10^{6} / 1\right)$. Twenty one $(26 \%)$ had AIDS, 41 (51\%) were coinfected with hepatitis C, and five $(6 \%)$ also had chronic hepatitis B.

Inmates were reviewed regularly to assess clinical status and adherence to antiretroviral treatment. As expected, they were significantly more likely to keep 
appointments compared with our hospital outpatient cohort (88\% (446/509) v 67\% (1098/1645); $\mathrm{P}<0.001)$. Reasons for non-attendance included attendance at court or hospital or a legal or social visit (35\%; 22/63), transfer to another prison $(25 \% ; 16 / 63)$, failure to locate prisoner $(13 \% ; 8 / 63)$, and lack of clinic time $(6 \% ; 4 / 63)$.

Sixteen of $34(47 \%)$ inmates incarcerated after 1996 who were eligible for antiretroviral treatment according to national guidelines were taking it. ${ }^{3}$ In comparison, $76 \%(493 / 649)$ of outpatients were already taking or started antiretroviral treatment within six months of their CD4 count dropping below $350 \times 10^{6} / 1$.

Seven of 18 inmates who had not been taking antiretroviral treatment started taking it in prison. The remainder were seen on only a few occasions, which was considered insufficient to initiate and monitor treatment (median $=3$; range $2-6$ ).

Self reported adherence to antiretroviral treatment exceeded $90 \%$, which compares favourably with the rate reported from a London outpatient cohort. ${ }^{4}$ Nineteen of $30(63 \%)$ inmates reported occasions when they had not received their medication as prescribed. Reasons included confinement to cell and travel to court, hospital, or another prison. Prescription error and drug unavailability were cited infrequently.

Fifteen (19\%) inmates required at least one admission to hospital for a median of seven days (range 3-84). The spectrum of clinical problems included respiratory tract infections, investigation of possible mycobacterium tuberculosis $(n=12)$, treatment of lymphoma or Kaposi's sarcoma $(n=2)$, meningitis $(\mathrm{n}=2)$, complications from hepatitis $\mathrm{C}(\mathrm{n}=1)$, and neuropsychiatric problems $(\mathrm{n}=1)$.

\section{Comment}

Our HIV service is used by a high proportion of severely immunosuppressed prisoners, who present complicated management issues. Almost a quarter of prisoners who claimed to be positive for HIV-1 antibody were not, although the proportion may be higher because a considerable number declined confirmatory testing. We therefore recommend that HIV status be confirmed in all prisoners.

Imprisonment presents an opportunity for inmates to have closely supervised specialist HIV care. ${ }^{5}$ We identified several logistical problems that had an impact on patient monitoring and adherence to antiretroviral treatment. The provision of services to prisoners who are positive for HIV-1 antibody must be regularly audited to identify obstacles to effective healthcare delivery.

We thank Natalie Ives for assisting with the statistical analysis.

Contributors: SE designed the study, data extraction and analysis, and drafted the paper and organised its final production. MTF, PH, and JB assisted in data extraction. CT conceived the idea, guided the study design, and provided support in preparing the manuscript. NH set up the service contract. PE contributed to the data interpretation and provided support in preparing the manuscript. SE, CT, MTF, PH, and JB delivered the service for which the data are based. All authors commented on drafts of this publication. CT is the guarantor.

Funding: None.

Competing interests: None declared.

1 Her Majesty's Chief Inspector of Prisons. Patient or prisoner? A new strategy for health care in prisons. London: Home Office, 1996.

2 Joint Prison Service and National Health Service Executive Working Group. The future organisation and delivery of prison health care. London: Home Office, 1999.

3 BHIVA Guidelines Co-ordinating Committee. British HIV Association guidelines for antiretroviral treatment of HIV seropositive individuals. Lancet 1997;349:1086-92.

4 Walsh JC, Dalton M, Gill J, Burgess AP, Gazzard BG. Adherence to highly active antiretroviral therapy (HAART). In: Program and abstracts of the 38th Interscience Conference on Antimicrobial Agents and Chemotherapy, 24-27 September, 1998; San Diego. (Abstract I-171.)

5 Dixon PS, Flannigan TP, DeBuono BA, Laurie JJ, Hoy J, Stein M, et al. Infection with the human immunodeficiency virus in prisoners: meeting the health care challenge. Am J Med 1993;95:629-35.

(Accepted 18 September 2000.)
Department of Genitourinary/HIV Medicine, Caldecot Centre, King's College Hospital, London SE5 9RS Simon Edwards specialist registrar Melinda

Tenant-Flowers

consultant

Joseph Buggy health adviser

Peter Horne health adviser Nick Hulme clinic manager Philippa Easterbrook professor

Chris Taylor consultant

\section{A memorable patient Lessons in communication}

When I was a final year medical student at Birmingham University it was customary to gain your first experience of obstetrics and gynaecology in a different region. On my first morning I wandered down to the operating theatres with some trepidation-I had already heard that Mr X, the consultant to whom I was attached, could be "a little difficult." Things got off to an imperfect start when I got lost and blundered into the theatres without having donned my greens. Already feeling an inch tall, I dressed more appropriately and entered the main gynae theatre. After introducing myself to one of the operating department assistants I was directed towards the consultant. He was sitting on a stool, fully scrubbed, waiting for the anaesthetist to give him the go ahead to operate.

"Good morning Mr X, I'm Marcus Mulcahy, one of the medical students from Birmingham," I ventured. No reply-no acknowledgment even. I presumed that he had not heard me through his theatre hood and tried again, "Hello Mr X, I'm one of your new students." At this point the consultant got up and, without diverting his gaze, walked straight past me to the operating table. He began to perform the first operation of the day.
Not knowing what the first case was, I peered at the list on the wall: "Right ovarian cyst removal." I settled back into my customary medical student role of observation. The operation certainly seemed to be progressing pretty rapidly. Mr X did not seem too concerned about the blood loss; he was more intent on getting the cyst out quickly. However, what emerged was not a cyst but a screaming baby boy. Never having witnessed a birth before, let alone a caesarean section, I was quite taken aback by such an unexpected experience.

I suppose the lessons to be learnt from this are twofold. Firstly, if you're a consultant surgeon or a doctor in any teaching role, please make an effort to communicate with your students and, secondly, don't believe all you see on operating lists. Having said that, the birth of this most memorable of patients would not have been such a remarkable experience if my introduction to obstetrics had been a little more conventional.

Marcus Mulcahy senior house officer in public health, Walsall 